\title{
PENGELOLAAN DANA ZAKAT: STUDI AKUNTABILITAS DAN TRANSPARANSI ORGANISASI PENGELOLA ZAKAT DI KOTA BOGOR
}

\section{THE MANAGEMENT OF ZAKAT: STUDY OF ACCOUNTABILITY AND TRANSPARENCY IN ZAKAT MANAGEMENT ORGANIZATIONS IN BOGOR}

\author{
M. N. Mukmin, Susilawati \\ Jurusan Akuntansi Fakultas Ekonomi Universitas Djuanda Bogor \\ E-mail : Susilawati2015@unida.ac.id
}

\begin{abstract}
ABSTRACK
Management of zakat funds has been regulated by the state through Law Number 3 of 2011, from planning to distribution. Zakat funds can be managed by the Zakat Management Organization (OPZ). Bogor City has 6 OPZ that are the objects of this study. This study aims to examine whether there is an influence of accountability and transparency on the management of zakat funds in Zakat Management Organizations (OPZ). The data used is the processing of questionnaire responses to amil zakat (funders) at BAZNAS Bogor City, Rumah Zakat, LAZ AlBunyan, DPU (Darut Tauhid Cares Bogor), Yatim Mandiri, and Baytul Maal Bogor. There are 33 amil zakat as a sample. Testing and analysis of data using multiple linear regression analysis and all instruments in this study are valid and reliable and the model in this study is feasible. The results of the analysis and testing of the hypotheses performed showed that simultaneous and partial accountability and transparency affect the management of OPZ zakat funds in the city of Bogor.
\end{abstract}

\section{Keywords: Accountability, BAZNAS Bogor City, Transparency, Zakat Management Organization}

\begin{abstract}
ABSTRAK
Pengelolaan dana zakat telah diatur oleh negara melalui Undang-Undang Nomor 3 Tahun 2011, mulai dari perencanaan hingga pendistribusian. Dana zakat dapat dikelola oleh Organisasi Pengelola Zakat (OPZ). Kota Bogor memiliki 6 OPZ yang menjadi objek pada penelitian ini. Penelitian ini bertujuan untuk menguji apakah terdapat pengaruh akuntabilitas dan transparansi terhadap pengelolaan dana zakat di Organisasi Pengelola Zakat (OPZ). Data yang digunakan pengolahan jawaban kuesioner kepada amil zakat (funder) pada BAZNAS Kota Bogor, Rumah Zakat, LAZ Al-Bunyan, DPU (Darut Tauhid Peduli Bogor), Yatim Mandiri, dan Baytul Maal Bogor. Terdapat 33 amil zakat sebagai sampel. Pengujian dan analisis data menggunakan analisis regresi linear berganda dan semua instrumen dalam penelitian ini valid dan reliabel dan model dalam penelitian ini layak. Hasil analisis dan pengujian hipotesis yang dilakukan menunjukan bahwa secara simultan maupun parsial akuntabilitasdan transparansi berpengaruh terhadap pengelolaan dana zakat OPZ di Kota Bogor.
\end{abstract}

Kata Kunci: Akuntabilitas, BAZNAS Kota Bogor, Organisasi Pengelola Zakat, Transparansi 


\section{PENDAHULUAN}

Dalam catatan BAZNAS Kota Bogor potensi penerimaan zakat di wilayah Kota Bogor pada tahun 2017 sebesar Rp135 miliar. Sementara realisasi penerimaan zakat pada tahun 2017 yang tercatat di BAZNAS Kota Bogor hanya Rp4,1 miliar (BAZNAS Kota Bogor, 2018).

Berdasarkan hasil wawancara kepada 13 muzakki yang ada di Kota Bogor pada tanggal 4 Januari 2019 yang dilakukan di Masjid Raya Bogor yang merupakan pusatnya Kota Bogor. Hasil wawancara tersebut bahwa 13 muzakki menyalurkan sendiri zakat penghasilannya di lingkungan setempat yang mereka anggap sebagai mustahik atau membayar zakatnya melaui masjid daerahnya. Mereka beranggapan bahwa tidak membayar zakat keorganisaasi pengelola zakat karena ada ketakutan penyalahgunaan.

Untuk menangani hal tersebut, pemerintah menerbitkan UU No 23 Tahun 2011 tentang pengelolaan zakat dan Keputusan Menteri Agama (KMA) No. 333/2015 (http//pusat.baznas.go.id). Regulasi tersebut diharapkan mampu mendorong terbentukknya OPZ yang bijaksana dalam mengelola dana zakat yang disalurkan kepada masyarakat.

Pengelolaan dana zakat adalah kegiatan yang meliputi merencanakan, melaksanakan, dan mengoordinasikan dalam mengumpulkan, mendistribusikan, dan mendayagunakan zakat (UU No 23 Tahun 2011). Dalam UU No 23 Tahun 2011 tentang pengelolaan zakat pasal 1 ayat (2) bahwa "Pengelolaan dana zakat yang di kelola oleh OPZ dituntut mampu untuk menjamin transparansi dan akuntabilitas organisasi.

Akuntabilitas adalah suatu kewajiban pihak penyampai amanah yang dapat menggunakan pertanggungjawaban, penyajian, pelaporan, dan pengungkapan dalam semua kegiatan sehingga menjadi tanggungjawabnya kepada pihak pemberi amanah yang memiliki hak dan kewenangan untuk meminta pertanggungjawaban tersebut (Setiawan dan Andris, 2019). Sedangkan transparansi adalah dasar kebebasan untuk memperoleh informasi yang dibutuhkan oleh masyarakat (Kusuma dkk, 2019).

Adapun pelaporan terhadap penyaluran yang telah dikumpulkan selama ini belum berjalan dengan maksimal. Kurang maksimalnya pelaporan dana OPZ didukung oleh hasil penelitian yang dilakukan oleh Nurhayati dan Fadilah (2018) yang menunjukkan bahwa masih terdapat lembaga yang dalam pengelolaan dana zakatnya belum relevan dengan PSAK 109.

Pernyataan Standar Akuntansi Keuangan 109 tentang Akuntansi Zakat merupakan pernyataan memiliki tujuan mengelola pengakuan, pengukuran, penyajian dan pengungkapan transaksi zakat dan infak/ sedekah (IAI, 2015). Hal inilah yang menjadi tujuan IAI dengan menerbitkan PSAK 109 supaya menjadi dasar OPZ dalam menyusun dan menyajikan laporan keuangan yang diharapkan dapat meningkatkan transparansi dan laporan keuangan yang berkualitas sehingga dapat berguna bagi para pemakainya.

Adapun perbedaan penelitian ini dengan penelitian terdahulu adalah variabel independen yang digunakan pada penelitian terdahulu memakai varibel akuntabilitas dan transparansi. Maka dari itu penulis mencoba menambahkan variabel penerapan PSAK 109. Alasan merujuk pada PSAK 109 adalah penelitian yang dilakukan sebelumnya menyatakan bahwa penerapan PSAK 109 memliki pengaruh signifikan dan positif terhadap pengelolaan zakat. Perbedaan lainnya yaitu dari periode waktu dan lokasi penelitian. Penelitian ini dilakukan pada organisasi pengelola zakat yang ada di Kota Bogor.

\section{Rumusan Masalah}


1. Apakah Akuntabilitas berpengaruh secara parsial terhadap Pengelolaan

2. Apakah Transparansi berpengaruh secara parsial terhadap Pengelolaan Dana Zakat?

3. Apakah Penerapan Standar Akuntansi Syariah (PSAK 109) berpengaruh secara parsial terhadap Pengelolaan Dana Zakat?

4. Apakah Akuntabilitas, Transparansi dan Penerapan Standar Akuntansi Syariah (PSAK 109) secara simultan berpengaruh terhadap Pengelolaan Dana Zakat?

\section{Variabel Penelitian Dan Definisi}

Operasional variabel

Variabel Independen dalam penelitian ini ialah Akuntabilitas, Transparansi dan

\section{Dana Zakat?}

\section{METODE PENELITIAN}

Penelitian ini berkenaan dengan akuntabilitas, akuntabilitas dan penerapan PSAK 109 terhadap pengelolaan dana zakat pada OPZ di Kota Bogor. Data yang digunakan pada penelitian ini adalah asosiatif, yakni penelitian yang menguji hubungan atau hubungan antara variabel, dua variabel atau lebih.

Penerapan PSAK 109. Sedangkan variabel dependennya ialah Pengelolaan Dana Zakat. Berikut ini adalah tabel 1 oprasional variabel.

\section{Tabel 1}

Definisi Operasional Variabel

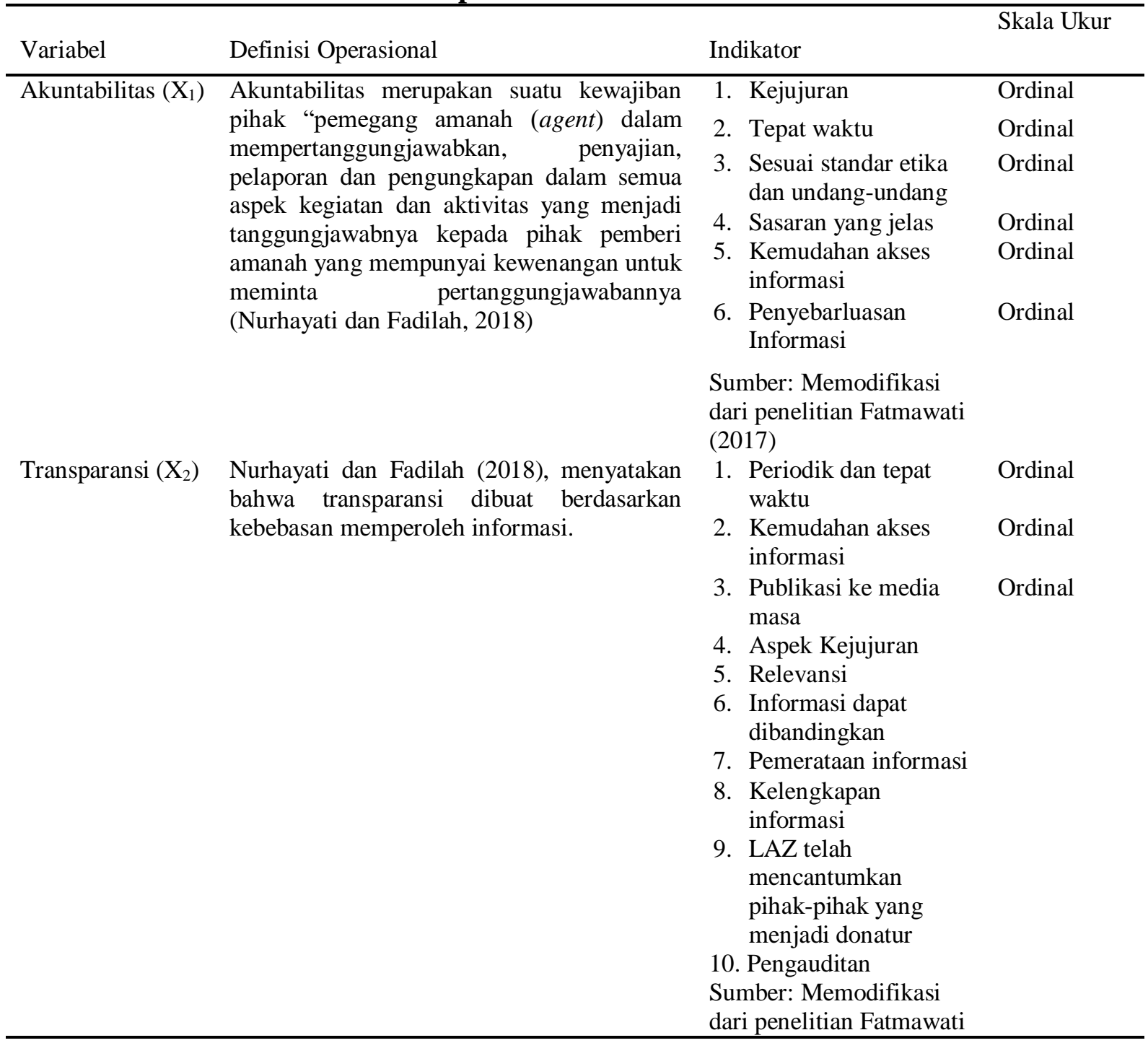




\begin{tabular}{|c|c|c|c|}
\hline & & (2017) & \\
\hline $\begin{array}{l}\text { Penerapan } \\
\text { Standar } \\
\text { Akuntansi } \\
\text { Syariah (PSAK } \\
\text { 109) }\left(\mathrm{X}_{3}\right)\end{array}$ & $\begin{array}{l}\text { PSAK } 109 \text { Akuntansi Zakat Dan Infak/ } \\
\text { Sedekah adalah pernyataan yang memiliki } \\
\text { tujuan dalam mengelola pengakuan, } \\
\text { mengukur, menyajikan dan mengungkapkan } \\
\text { transaksi zakat dan infak/ sedekah (IAI, } \\
\text { 2015). }\end{array}$ & $\begin{array}{l}\text { 1. Pengakuan dan } \\
\text { Pengukuran } \\
\text { 2. Penyajian } \\
\text { 3. Pengungkapan } \\
\text { Sumber: IAI, } 2015\end{array}$ & $\begin{array}{l}\text { Ordinal } \\
\text { Ordinal } \\
\text { Ordinal }\end{array}$ \\
\hline $\begin{array}{l}\text { Pengelolaan Dana } \\
\text { Zakat (Y) }\end{array}$ & $\begin{array}{l}\text { UU No. } 23 \text { tahun } 2011 \text { tentang Pengelolaan } \\
\text { Zakat, pengelolaan zakat merupakan } \\
\text { aktifitas yang meliputi merencanakan, } \\
\text { melaksanakan, dan mengoordinasikan dalam } \\
\text { mengumpulkan, mendistribusikan, dan } \\
\text { mendayagunakan zakat. }\end{array}$ & $\begin{array}{l}\text { 1. Manajemen } \\
\text { Penghimpun } \\
\text { (Fundarising } \\
\text { Management) } \\
\text { 2. Manajemen } \\
\text { Pendistribusi an dan } \\
\text { Pendayaguna an. } \\
\text { 3. Manajemen } \\
\text { Keuangan dan } \\
\text { Akuntansi } \\
\text { Sumber: Nurhayati dan } \\
\text { Fadilah, 2018 }\end{array}$ & $\begin{array}{l}\text { Ordinal } \\
\text { Ordinal }\end{array}$ \\
\hline
\end{tabular}

Sumber: Hasil Pengolahan, 2019.

\section{Populasi dan Sampel Penelitian}

Populasi penelitian ini ialah amil zakat sebanyak 83 amil zakat dari 6 organisasi pegelola zakat di Kota Bogor. Teknik pengambilan sampel Menurut Sugiyono (2018:96) purposive sampling adalah metode dalam menentukan sampel dalam mempertimbangkan hal-hal tertentu.
Sehingga dari 83 populasi setelah dipurposive menghasilkan 33 sampel.

\section{Pengujian Data}

Instrumen untuk mengukur ketiga variabel dalam penelitian menggunakan kuesioner. Tabel 2 Penilaian Kuesioner

Tabel 2 Penialian Kuisioner

\begin{tabular}{cc}
\hline Jawaban Responden & Bobot Nilai \\
\hline Sangat Setuju & 5 \\
Setuju & 4 \\
Ragu-Ragu & 3 \\
Tidak Setuju & 3 \\
Sangat Tidak Setuju & 1 \\
\hline
\end{tabular}

Sumber: Sugiyono (2018: 135).

\section{Uji Validitas}

Uji validitas merupakan uji yang dapat mengukur tingkat kebenaran suatu instrumen (Arikunto, 2014: 211). Untuk uji ini digunakan tabel Correlations dimana uji signifikansi memperbandingkan nilai $r$ hitung dengan $\mathrm{r}$ tabel, jika $\mathrm{r}$ hitung $>\mathrm{r}$ tabel dan bernilai positif, sehingga pernyataan tersebut dikatakan valid. Sedangkan jika $\mathrm{r}$ hitung $<\mathrm{r}$ tabel, maka item tersebut dinyatakan tidak valid (Arikunto: 2014: 212). Tarif signifikan dalam penelitian ini sebesar 5\%. Rumus yang digunakan adalah:

$$
r=\frac{N \Sigma x y-\left(\sum x\right)\left(\sum y\right)}{\sqrt{\left(N \Sigma x^{2}-\left(\sum x\right)^{2}\left(N \Sigma y^{2}-(\Sigma y)^{2}\right)\right.}}
$$

Dimana:

$$
\begin{aligned}
& \mathrm{r}=\text { Koefesien validitas yang dicari } \\
& \mathrm{xy}=\text { Jumlah perkalian item dengan } \\
& \text { total item } \\
& \mathrm{x}=\text { Tingkat skor indikator yang diuji } \\
& \text { dari setiap pertanyaan } \\
& \mathrm{y} \quad=\text { Total skor indikator } \\
& \mathrm{n} \quad=\text { Jumlah Responden }
\end{aligned}
$$


Tabel 3 Kriteia Uji Validitas

\begin{tabular}{cc}
\hline Correted Item Total Corelation & Keterangan \\
\hline$\geq 0,3$ & Valid \\
$\leq 0,3$ & Tidak Valid \\
\hline
\end{tabular}

Sumber: Sugiyono, 2018: 179.

\section{Uji Reliabilitas}

Uji reliabilitas adalah uji statistik yang digunakan guna menentukan reliabilitas serangakaian item pertanyaan dalam keandalannya mengukur suatu variabel. Uji reliabilitas ini menggunakan metode Cronbach 's Alpha. Suatu item dinyatakan reliabel jika nilai Cronbach $>0,70$ (Arikunto: 2014: 222).

Dengan kriteria bahwa suatu instrumen dilakukan realibel apabila memnuhi standar koefisien Alpa Cronbach $>0,70$. Sedangkan kriteria uji realibilitas dapat dilihat pada tabel 4 berikut:

Tabel 4 Kriteia Uji Reliabilitas

\begin{tabular}{clc}
\hline Alpha & Croncbach & Keterangan \\
\hline & $\geq 0,7$ & Reliabel \\
& $\leq 0,7$ & Tidak Reliabel \\
\hline
\end{tabular}

Sumber: Ghozali, 2016.

\section{Uji Asumsi Klasik}

Sebelum melakukan pengujian hipotesis, dilakukan uji asumsi klasik terlebih dahulu yang mendasari dan menjadi persyaratan statistik yang perlu dipenuhi dalam penggunaan analisis regresi dan koefesien regresi yang linier, tidak bias, konsisten, serta efisien. Asumsi klasik menurut Ghozali (2011) adalah uji normalitas, uji multikolonieritas dan uji hateroskedastistas.

\section{Regresi Linier Berganda}

Sugiyono (2018: 206), menyatakan bahwa teknik regresi linier berganda (multiple regression analisis) digunakan untuk memprediksi bagaimana perubahan nilai variabel dependen, bila nilai variabel independen dinaikan atau di turunkan nilainya. Bentuk persamaan regresi yaitu sebagai berikut:

$\mathrm{Y}=\mathrm{a}+\beta_{1} \mathrm{X}_{1}+\beta_{2} \mathrm{X}_{2}+\beta_{3} \mathrm{X}_{3}+\epsilon$ Keterangan:

Y: Pengelolaan Dana Zakat

$\mathrm{X}_{1}$ : Akuntabilitas

$\mathrm{X}_{2:}$ Transparansi

$\mathrm{X}_{3}$ : Penerapan PSAK 109

A : Konstantan

$\beta$ : Koefisien regresi

$\beta_{1}$ : Koefisien Variabel Akuntabilitas

$\beta_{2}$ : Koefisien Variabel Transparansi

$\beta_{3}$ : Koefisien Variabel Penerapan Standar Akuntansi Syariah (PSAK 109)

\section{Koefisisen Korelasi Berganda}

Alat ini digunakan untuk mengetahui hubungan antara variabelvariabel bebas (x) terhadap variabel $(y)$.

Tabel 5 Tingkat Korelasi Variabel

\begin{tabular}{cc}
\hline Interval Korelasi & Tingkat Hubungan \\
\hline $0,00-0,119$ & Sangat Lemah \\
$0,20-0,399$ & Lemah \\
$0,40-0,599$ & Cukup Kuat \\
$0,60-0,799$ & Kuat \\
$0,80-1,000$ & Sangat Kuat \\
\hline
\end{tabular}


Sumber : Sugiyono, $2018: 250$.

\section{Koefisien Determinasi $\left(\mathbf{R}^{2}\right)$}

Koefisisen determinasi $\left(\mathrm{R}^{2}\right)$

digunakan untuk mengetahui tingkat kemampuan koefisien determinasi dalam menjelaskan bentuk variabel dependen.

\section{Uji F}

Pengujian yang dilakukan ini adalah dengan uji parameter $\beta$ (uji korelasi) dengan menggunakan uji $F$ statistik. Untuk menguji pengaruh variabel bebas secara simultan pada variabel dependen digunakan uji $F$. Dengan menggunakan tingkat kesalahan 0,05. Untuk uji $F$, kriteria yang dipakai adalah:

a. Jika f-hitung > f-tabel, maka HA diterima, artinya variabel bebas memiliki pengaruh signifikan pada variabel terikat secara simultan.

b. Jika f-hitung < f-tabel, maka HA ditolak, artinya variabel bebas tidak memiliki pengaruh signifikan pada variabel terikat secara simultan

Adapun dapat membandingkan dengan nilai signifikansi dengan nilai $\alpha$ sebagai berikut:

1. Apabila signifikansi $\leq 0,05$, maka $\mathrm{Ha}$ diterima

\section{HASIL DAN PEMBAHASAN}

\section{Objek/Subjek Penelitian}

Objek penelitian ini yaitu OPZ di Kota Bogor yang terdiri dari 6 OPZ yaitu BAZNAS Kota Bogor, Rumah Zakat, LAZ Al-Bunyan, DPU (Darut Tauhid Peduli
2. Apabila signifikansi $>0,05$, maka $\mathrm{Ha}$ ditolak

\section{Uji T}

Pengujian ini untuk mengetahui pengaruh satu variabel bebas secara individual dalam menjelaskan bentuk variabel terikat (Ghozali, 2016: 97). Kriteria penerimaan dan penolakan hipotesis yaitu:

a. Jika t-hitung > t tabel, maka HA diterima, artinya variabel bebas memiliki pengaruh signifikan terhadap variabel terikat secara parsial.

b. Jika t-hitung $<\mathrm{t}$ tabel, maka HA ditolak, artinya variabel bebas tidak memiliki pengaruh signifikan terhadap variabel terikat secara parsial.

Hasil perhitungan ini selanjutnya dibandingkan dengan ttabel dengan menggunakan tingkat kesalahan 0,05 uji dua pihak dan $d b=n-2$, kriteria sebagai berikut: Atau dengan membandingkan signifikansi dengan niali $\alpha$.

1. Apabila signifikansi $\leq 0,05$, maka $\mathrm{Ha}$ diterima

2. Apabila signifikansi $\geq 0,05$, maka $\mathrm{Ha}$ ditolak.

Bogor), Yatim Mandiri, dan Baytul Maal Bogor. Dan subjek penelitiannya adalah amil yang bekerja di bagian keuangan, pendistribusian, pendayagunaan dan pengumpulan pada 6 OPZ di Kota Bogor.

\section{Karakteristik Responden}




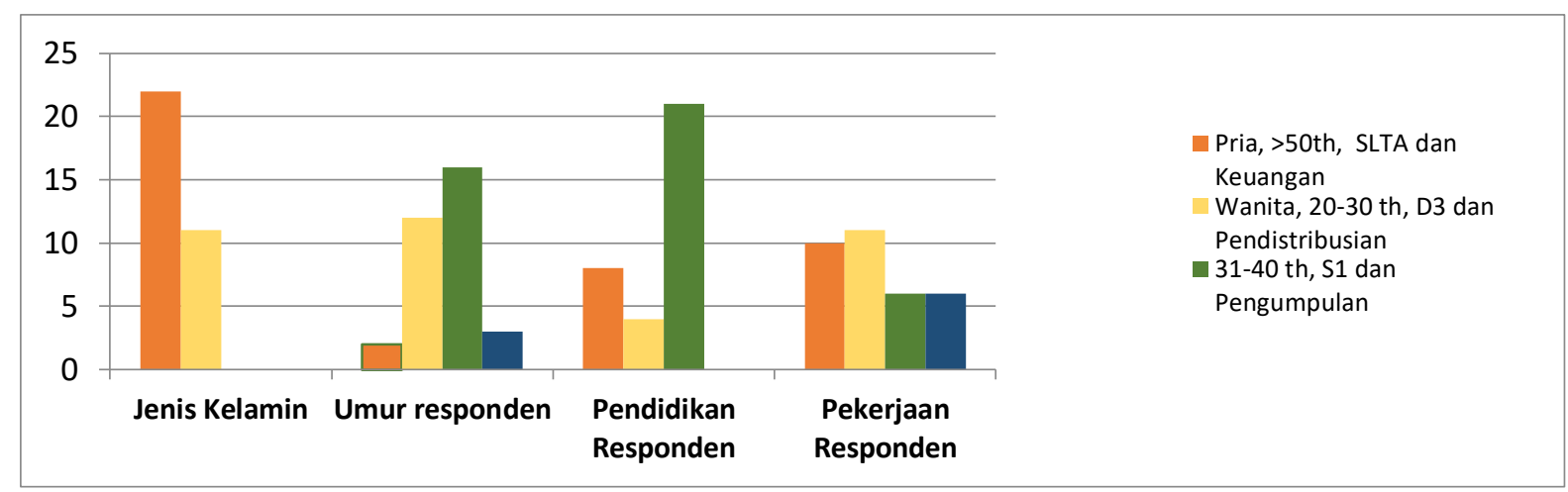

Sumber: Data primer yang diolah, 2019.

Tabel 4.5 Rekapitulasi Tanggapan Responden

\begin{tabular}{clcc}
\hline No. & \multicolumn{1}{c}{ Variabel } & Nilai Rata-Rata Skor & Keterangan \\
\hline 1. & Akuntabilits (X1) & 4,49 & Sangat Setuju \\
2. & Transparansi (X2) & 4,36 & Sangat Setuju \\
3. & Penerapan PSAK 109 (X3) & 4,20 & Setuju \\
4. & Pengelolaan Dana Zakat (Y) & 4,30 & Sangat Setuju \\
\hline
\end{tabular}

Sumber: Data primer yang diolah, 2019.

\section{Pengujian Instrumen}

Uji Validitas

Tabel 4.6 Rekapitulasi Uji Validitas

\begin{tabular}{lcccc}
\hline No & Variabel & r hitung & r kritis & Kesimpulan \\
\hline 1. & Akuntabilitas & 0,641 & 0,3440 & Valid \\
2. & Transparansi & 0,635 & 0,3440 & Valid \\
3. & Penerapan PSAK 109 & 0,665 & 0,3440 & Valid \\
4. & Pengelolaan Dana Zakat & 0,584 & 0,3440 & Valid \\
\hline
\end{tabular}

Sumber: Data primer yang diolah, 2019

Berdasarkan tabel tersebut

diketahui bahwa masing-masing item

pernyataan memiliki $r$ hitung $>r$ tabel

(0,3440) dan bernilai positif. Maka dapat

\section{Uji Realibilitas}

Tabel 4.7 Uji Realibilitas

\begin{tabular}{cccc}
\hline Variabel & Croncbach Alpha & Nilai Kritis & Ket \\
\hline Akuntabilitas (X1) & 0,714 & 0,70 & Realibel \\
Transparansi (X2) & 0,832 & 0,70 & Realibel \\
Penerapan PSAK 109 (X3) & 0,773 & 0,70 & Realibel \\
Pengelolaan Dana Zakat (Y) & 0,898 & 0,70 & Realibel \\
\hline
\end{tabular}

Sumber: Output pengolahan data dengan SPSS 22, 2019

Berdasarkan tabel 4.7, ditentukan nilai standar $r_{\text {kritis }}$ adalah sebesar 0,70 . Hasil uji reliabilitas dari setiap item menunjukan bahwa variabel akuntabilitas yaitu sebesar 0,837 , variabel transparansi yaitu 0,832, variabel penerapan PSAK 109 Zakat yaitu 0,889 semua nilai tersebut menunjukan lebih besar atau sama dengan 0,7 sehingga semua instrumen yang digunakan dapat dikatakan reliabel, dan layak digunakan. yaitu 0,773 , dan variabel Pengelolaan Dana 
Metode Analiis Data

Analisis Regresi Linear Berganda

Tabel 4.8 Hasil Uji Regresi Linear Berganda

\begin{tabular}{|c|c|c|c|c|c|c|}
\hline \multirow{2}{*}{\multicolumn{2}{|c|}{ Model }} & \multicolumn{2}{|c|}{$\begin{array}{l}\text { Unstandardized } \\
\text { Coefficients }\end{array}$} & \multirow{2}{*}{$\begin{array}{c}\text { Standardized } \\
\text { Coefficients } \\
\text { Beta }\end{array}$} & \multirow[t]{2}{*}{$\mathrm{T}$} & \multirow[t]{2}{*}{ Sig. } \\
\hline & & B & Std. Error & & & \\
\hline \multirow[t]{4}{*}{1} & (Constant) & 2,627 & 10,483 & & ,251 & ,804 \\
\hline & Akuntabilitas &, 720 & 321 & ,261 & 2,243 &, 033 \\
\hline & Transparansi & 895 & 235 & ,493 & 3,801 &, 001 \\
\hline & Penerapan & 667 &, 324 & 278 & 2,058 & 049 \\
\hline
\end{tabular}

a. Dependent Variable: Pengelolaan Dana Zakat

Sumber: Output pengolahan data dengan SPSS 22, 2019

Berdasar tabel 4.8 diperoleh hasil perhitungan regresi linier

berganda sebagai berikut:

$\mathrm{Y}=2,627+0,720 \mathrm{X} 1+0,895 \mathrm{X} 2+0,667$

$\mathrm{X} 3+\varepsilon$

Interpretasi dari hasil regresi adalah sebagai berikut ini:

1. Konstanta

Nilai konstanta dari persamaan diatas adalah sebesar 2,627. Hal ini berarti bahwa jika variabel independen diasumsikan bernilai nol (0), maka nilai variabel terikat (Pengelolaan Dana Zakat) sebesar 2,627.

2. Akuntabilitas (X1) terhadap Pengelolaan Dana Zakat (Y)

Variabel Akuntabilitas (X1) mempunyai pengaruh positif dalam meningkatkan pengelolaan dana zakat. Hal ini di tunjukan dengan koefisien regresi sebesar 0,720, ini berarti jika terjadi peningkatan variabel akuntabilitas (X1) sebesar satu satuan dengan asumsi variabel lain konstan maka besarnya pengelolaan dana zakat (Y) akan naik sebesar 0,720 .

3. Transparansi (X2) terhadap Pengelolaan Dana Zakat (Y)

Variabel Transparansi (X2) mempunyai pengaruh positif dalam meningkatkan pengelolaan dana zakat. Hal ini di tunjukan dengan koefisien regresi sebesar 0,895, ini berarti jika terjadi peningkatan variabel transparansi (X2) sebesar satu satuan dengan asumsi variabel lain konstan maka besarnya pengelolaan dana zakat (Y) akan naik sebesar 0,895.

4. Penerapan PSAK 109 (X3) terhadap Pengelolaan Dana Zakat (Y)

Variabel Penerapan PSAK 109

(X3) mempunyai pengaruh positif dalam meningkatkan pengelolaan dana zakat. Hal ini di tunjukan dengan koefisien regresi sebesar 0,667, ini berarti jika terjadi peningkatan variabel Penerapan PSAK 109 (X3) sebesar satu satuan dengan asumsi variabel lain konstan maka besarnya pengelolaan dana zakat (Y) akan naik 0,667.

\section{Koefisien Korelasi Berganda}

Tabel 4.10 Koefisien Korelasi Berganda

Model Summary ${ }^{\mathrm{b}}$

\begin{tabular}{lrrrrr}
\hline Model & $\mathrm{R}$ & $\mathrm{R}$ Square & $\begin{array}{l}\text { Adjusted } \\
\text { R Square }\end{array}$ & $\begin{array}{r}\text { Std. Error of } \\
\text { the Estimate }\end{array}$ & Durbin-Watson \\
\hline 1 &, $817^{\mathrm{a}}$ &, 667 &, 632 & 3,172 & 1,662 \\
\hline
\end{tabular}

Sumber: Output pengolahan data dengan SPSS 22, 2019

Berdasarkan tabel 4.60 tersebut, diperoleh nilai $\mathrm{R}$ sebesar 0,817 yang menunjukan bahwa nilai $\mathrm{R}(0,817)$ tersebut berada pada interval nilai $\mathrm{R}(0,800-0,1000)$ yang memiliki derajat kekuatan hubungan yang sangat kuat, sehingga terdapat pengaruh yang sangat kuat antara akuntabilitas, transparansi, dan penerapan 
PSAK 109 secara bersama-sama terhadap pengelolaan dana zakat. Hal tersebut berarti bahwa semakin baik akuntabilitas, transparansi, dan penerapan PSAK 109 secara bersama-sama maka semakin meningkatkan pengelolaan dana zakat.

\section{Koefisien Determinasi $\left(\mathbf{R}^{2}\right)$}

Tabel 4.11 Koefisien Determinasi

Model Summary ${ }^{b}$

\begin{tabular}{lrrrrr}
\hline Model & $\mathrm{R}$ & R Square & $\begin{array}{l}\text { Adjusted } \\
\text { R Square }\end{array}$ & $\begin{array}{r}\text { Std. Error of } \\
\text { the Estimate }\end{array}$ & Durbin-Watson \\
\hline 1 &, $817^{\text {a }}$ &, 667 &, 632 & 3,172 & 1,662 \\
\hline
\end{tabular}

Sumber: Output pengolahan data dengan SPSS 22, 2019.

Berdasarkan tabel diatas diperoleh nilai Adjusted $\mathrm{R}$ Square sebesar 0,632. Angka tersebut menjelaskan bahwa sebanyak 0,632 atau sama dengan 63,2\% menunjukkan OPZ yang ada di Kota Bogor dipengaruhi oleh akuntabilitas, transparansi dan penerapan PSAK 109. Hal ini menjukkan bahwa variabel bebas dapat menjelaskan varibael terikat dengan cukup baik, karena Adjusted $R$ Square lebih besar dar 0,5 . Sedangkan sisanya sebesar 0 , atau sama dengan 36,8\% (100\% - 63,2\% = $36,8 \%$ ) dijelaskan dalam faktor lainnya yang tidak diteliti atau diluar model tersebut.

\section{Pengujian Hipotesis}

Pengujian Hipotesis dengan Uji F

\begin{tabular}{llcrrrr}
\multicolumn{7}{c}{ Tabel 4.12 Uji F } \\
\multicolumn{7}{c}{ ANOVA $^{\mathbf{a}}$} \\
\hline \multirow{2}{*}{ Model } & Sum of & Df & Mean & F & Sig. \\
& & Squares & & Square & & \\
\hline 1 & Regression & 584,140 & 3 & 194,713 & 19,335 &, $000^{\mathrm{b}}$ \\
& Residual & 291,739 & 29 & 10,060 & & \\
& Total & 875,879 & 32 & & & \\
\hline
\end{tabular}

a. Dependent Variable: Pengelolaan Dana Zakat

b. Predictors: (Constant), Penerapan PSAK 109, Akuntabilitas, Transparansi Sumber: Output pengolahan data dengan SPSS 22, 2019

Dari tabel tersebut, terlihat bahwa nilai $\mathrm{F}$ hitung sebesar 19,042 lebih besar dari $\mathrm{F}$ tabel sebesar 2,95 dengan nilai probabilitas $(\mathrm{sig})=0,000$ nilai sig lebih kecil dari nilai probabilitas 0,05 atau $0,000<0,05$; maka Ha diterima, berarti model regresi ini dapat

\section{Pengujian Hipotesis dengan Uji T}

Pada dasarnya uji $\mathrm{T}$ mengetahui kemampuan pengaruh suatu variabel bebas secara individual dalam menjelaskan bentuk variabel terikat. Adapun prosedurnya adalah sebagai berikut: diakatan bahwa variabel akuntabilitas, transparansi dan penerapan PSAK 109 secara bersama-sama berpengaruh terhadap pengelolaan dana zakat di OPZ di Kota Bogor.

Tabel 4.13 Uji T

Ho $=$ Tidak terdapat pengaruh positif dan signifikan dari variabel independen pada variabel dependen

$\mathrm{Ha}=$ Terdapat pengaruh positif dan signifikan dari variabel independen pada variabel dependen.

\begin{tabular}{lcccc}
\hline Model & $\begin{array}{c}\text { Unstandardized } \\
\text { Coefficients }\end{array}$ & $\begin{array}{c}\text { Standardized } \\
\text { Coefficients }\end{array}$ & T & Sig.
\end{tabular}




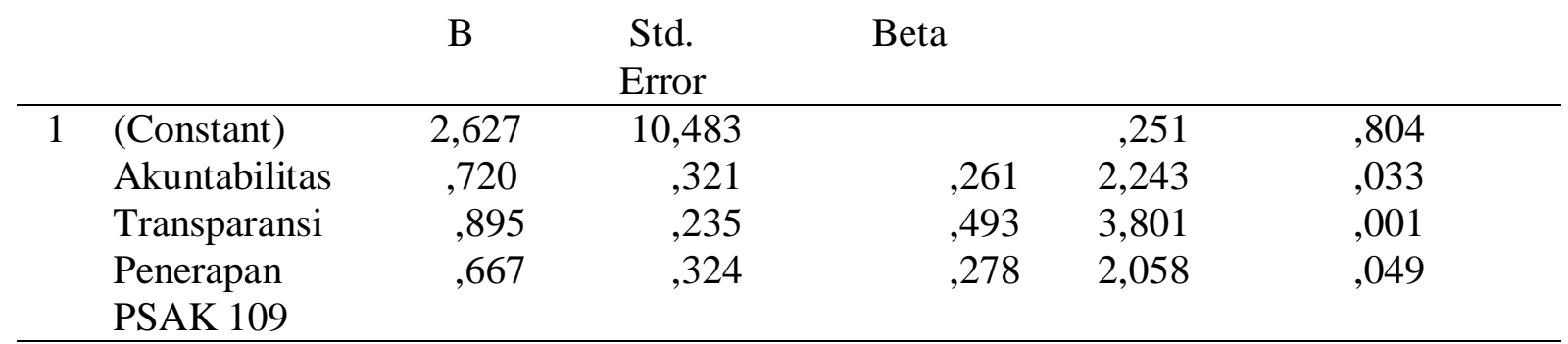

Dependent Variable: Pengelolaan Dana Zakat

Sumber: Output pengolahan data dengan SPSS 22, 2019

Berdasarkan tabel 4.13 tersebut,

pembuktian hipotesis dapat dijelaskan sebagai berikut:

1. Hipotesis pertama yang menyatakan akuntabilitas memiliki pengaruh positif dan sigifikan terhadap pengelolaan dana zakat" telah terbukti kebenarannya. Faktor akuntabilitas pada uji $\mathrm{t}$ parsial memiliki nilai signifikansi sebesar 0,033 dimana model memiliki nilai sig < level of signifikasi $(\alpha=0,05)$ dan nilai $t$ hitung lebih besar dibanding $t$ tabel yaitu sebesar 2,243>1,6991, maka hipotesis nol ditolak yang berarti bahwa faktor akuntabilitas berpengaruh positif dan signifikan terhadap pengelolaan dana zakat di Kota Bogor.

2. Hipotesis kedua yang menyatakan "transparansi memiliki pengaruh positif dan sigifikan terhadap pengelolaan dana zakat" telah terbukti kebenarannya. Faktor transparansi pada uji $t$ parsial memiliki nilai signifikansi sebesar 0,001 dimana model memiliki nilai sig < level of signifikasi $(\alpha=0,05)$ dan nilai $t$ hitung lebih besar dibanding $t$ tabel yaitu sebesar $3,801>1,6991$, maka hipotesis nol ditolak yang berarti bahwa faktor transparansi berpengaruh positif dan sigifikan terhadap pengelolaan dana zakat di Kota Bogor.

3. Hipotesis ketiga yang menyatakan "akuntabilitas memiliki pengaruh positif dan sigifikan terhadap pengelolaan dana zakat" telah terbukti kebenarannya. Faktor

akuntabilitas pada uji $\mathrm{t}$ parsial memiliki nilai signifikansi sebesar 0,049 dimana model memiliki nilai sig < level of signifikasi $(\alpha=0,05)$ dan nilai $t$ hitung lebih besar dibanding $\mathrm{t}$ tabel yaitu sebesar 2,058>1,6991, maka hipotesis nol ditolak mengartikan bahwa faktor akuntabilitas berpengaruh positif dan sigifikan pada pengelolaan dana zakat di Kota Bogor.

\section{Pengaruh Akuntabilitas, Transparansi dan Penerapan PSAK 109 Secara Parsial terhadap pengelolaan Dana Zakat \\ Pengaruh Akuntabilitas Secara Parsial terhadap Pengelolaan Dana Zakat}

Berdasarkan hasil pengujian variabel akuntabilitas $\left(\mathrm{X}_{1}\right)$ secara parsial berpengaruh positif dan signifikan pada pengelolaan dana zakat. Berdasarkan hasil uji regresi linear berganda menyatakan bahwa setiap peningkatan akuntabilitas sebesar satu satuan maka akan mempengaruhi pengelolaan dana zakat sebesar 0,720 pada asumsi bahwa variabel lain tetap. Selain itu berdasarkan uji parsial, akuntabilitas berpengaruh positif dan signifikan pada pengelolaan dana zakat. Artinya semakin baik akuntabilitas maka akan meningkatkan pengelolaan dana zakatnya. Akuntabilitas menjadi salah satu faktor penting dalam pengelolaan dana zakat. Hal tersebut ditunjukan dengan ratarata jawaban responden pada variabel akuntabilitas menunjukan nilai interprestasi yang sangat baik dan 
responden sangat setuju dengan pernyataan-pernyataan berikut ini:

a. Pertanggungjawaban laporan keuangan dana zakat telah memberikan informasi tentang laporan yang sesungguhnya. Pernyataan tersebut akan ada kaitannya terhadap pernyataan pengelolaan dana zakat yaitu telah dibuatnya sistem pengelolaan pelaporan dana zakat dan telah mensosialisasikan laporan dana zakat melalui berbagai media.

b. Laporan pertanggungjawaban sudah disampaikan kepada pemerintah dengan tepat waktu. Pernyataan tersebut akan ada kaitannya terhadap pernyataan pengelolaan dana zakat yaitu telah diterbitkannya laporan keuangan dana zakat dan analisis keuangan dana zakat secara periodik dan tepat waktu.

c. Laporan pertanggungjawaban OPZ mudah dipahami, diakses dan bersifat terbuka bagi pihak-pihak yang berkepentingan. Pernyataan tersebut akan ada kaitannya terhadap pernyataaan pengelolaan dana zakat yaitu telah dilakukannya sosialisasi melalui kerja saama dengan media cetak dan elektronik (Koran, radio dan televisi).

d. Laporan pertanggungjawaban OPZ disampaikan kepada masyarakat dan telah mencerminkan kepentingan dan kebutuhan. Pernyataan tersebut akan ada kaitannya terhadap pernyataan pengelolaan dana zakat yaitu telah diselenggarakannya program layanan mustahik untuk membantu mereka yang membutuhkan.

Berdasarkan pernyataan-pernyataan tersebut dapat disimpulkan bahwa aspek akuntabilitas memiliki pengaruh terhadap pengelolaan dana zakat. Hasil ini relevan dengan penelitian yang dilakukan oleh Fatmawati (2017) yang menyatakan bahwa akuntabilitas berpengaruh terhadap pengelolaan dana zakat di Kabupaten Sukoharjo. Selain itu, juga relevan dengan penelitian Nurhayati dan Fadilah (2018),
Muhammad (2016), serta Yuliafitri dan Khoiriyah (2016) yang menyatakan bahwa akuntabilitas berpengaruh terhadap tingkat penerimaan zakat. Semakin tinggi akuntabilitas suatu organisasi, maka akan semakin baik pengelolaan zakat. Maka dari itu, organisasi harus meningkatkan akuntabilitas. Hal ini dapat dilkaukan dengan cara melaporkan hasil pengelolaan zakat secara periodik, tepat waktu dan apa adanya.

\section{Pengaruh Transparansi Secara Parsial terhadap Pengelolaan Dana Zakat}

Berdasarkan hasil pengujian variabel transparansi $\left(\mathrm{X}_{2}\right)$ secara parsial berpengaruh positif dan signifikan pada pengelolaan dana zakat. Berdasarkan hasil uji regresi linear berganda menyatakan bahwa setiap peningkatan transparansi sebesar satu satuan maka akan mempengaruhi pengelolaan dana zakat sebesar 0,895 pada asumsi bahwa variabel lain tetap. Selain itu berdasarkan uji parsial, transparansi berpengaruh positif dan signifikan pada pengelolaan dana zakat. Artinya semakin baik transparansi maka akan meningkatkan pengelolaan dana zakatnya. Transparansi menjadi salah satu faktor penting dalam pengelolaan dana zakat. Hal tersebut ditunjukan dengan ratarata jawaban responden pada variabel transparansi menunjukan nilai interprestasi yang sangat baik dan responden sangat setuju dengan pernyataan-pernyataan berikut ini:

a. OPZ telah menyajikan laporan keuangan secara periodik dan tepat waktu. Pernyataan tersebut akan ada kaitannya terhadap pernyataan pengelolaan dana zakat yaitu telah diterbitkannya laporan keuangan dana zakat dan analisis keuangan secara periodik dan tepat waktu.

b. Informasi mengenai pengelolaan zakat dapat dengan mudah diakses oleh muzakki. Pernyataan tersebut akan ada kaitannya terhadap pernyataan pengelolaan dana zakat yaitu telah 
disosialisasikannya laporan keuangan dana zakat melalui berbagai media.

c. Laporan pertanggung jawaban OPZ mampu meningkatkan kepercayaan publik terhadap OPZ. Pernyataan tersebut akan ada kaitannya terhadap pernyataan pengelolaan dana zakat yaitu telah diakukannya upaya-upaya untuk meraih tingkat amanah, dan transparan dalam hal akuntansi, akuntabilitas, dan aksestabilitas pengelolaan dana

d. OPZ telah mencantumkan pihak-pihak yang menjadi donatur. Pernyataan tersebut akan ada kaitannya terhadap pernyataan pengelolaan dana zakat yaitu telah mengoptimalkan dan meningkatkan kualitas layanan donatur.

Berdasarkan pernyataan-pernyataan tersebut dapat disimpulkan bahwa aspek transparansi memiliki pengaruh terhadap pengelolaan dana zakat. Hasil ini relevan dengan Fatmawati (2017) yang menyatakan bahwa transparansi berpengaruh positif terhadap pengelolaan dana zakat. Selain itu, juga relevan dengan penelitian Fadilah (2018), Muhammad (2016), serta Yuliafitri dan Khoiriyah (2016), yang menyatakan bahwa akuntabilitas dan transparansi berpengaruh pada tingkat penerimaan zakat.

\section{Pengaruh Penerapan Standar Akuntansi Syariah (PSAK 109 ) Secara Parsial terhadap Pengelolaan Dana Zakat}

Berdasarkan hasil pengujian variabel penerapan PSAK $109\left(\mathrm{X}_{3}\right)$ secara parsial berpengaruh positif dan signifikan pada pengelolaan dana zakat. Berdasarkan hasil uji regresi linear berganda menyatakan bahwa setiap peningkatan penerapan PSAK 109 sebesar satu satuan maka akan mempengaruhi pengelolaan dana zakat sebesar 0,667 pada asumsi bahwa variabel lain tetap. Selain itu berdasarkan uji parsial, penerapan PSAK 109 berpengaruh positif dan signifikan pada pengelolaan dana zakat. Artinya semakin baik penerapan standar akuntansi syariah (PSAK 109) maka akan meningkatkan pengelolaan dana zakatnya. Penerapan PSAK 109 tentang akuntansi zakat menjadi salah satu faktor penting dalam pengelolaan dana zakat. Hal tersebut ditunjukan dengan rata-rata jawaban responden pada variabel transparansi menunjukan niali interprestasi yang baik dan responden setuju dengan pernyataanpernyataan berikut ini:

a. Penetuan jumlah atau presentase bagian untuk masing-masing mustahik ditentukan oleh amil sesuai dengan prinsip syariah, kewajaran, etika, dan ketentuan yang berlaku. Pernyataan tersebut akan ada kaitannya terhadap pernyataan pengelolaan dana zakat yaitu telah dimilikinya standar indikator mustahik dan memiliki pedoman batas kemiskinan mustahik dan memiliki sistem informasi zakat yang terpadu antar amil, sehingga menghindari penyaluran zakat pada mustahik yang sama.

b. Amil melakukan penyajian dana zakat, dan dana amil dengan terpisah pada laporan posisi keuangan. Pernyataan tersebut akan ada kaitannya terhadap pernyataan pengelolaan dana zakat yaitu telah dibuatnya sistem pengelolaan dan pelaporan keuangan secara periodik dan tepat waktu.

c. Mengungkapkan rincian terkait jumlah penyaluran dan zakat untuk masingmasing mustahik. Pernyataan tersebut akan ada kaitannya terhadap pernyataan pengelolaan dana zakat yaitu telah disosialisasikannya laporan keuangan dana zakat dan melakukan upaya-upaya untuk meraih tingkat amanah dan transparan dalam akuntansi, dan aksestabilitas pengelolaan dana zakat.

Berdasarkan pernyataan-pernyataan tersebut dapat disimpulkan bahwa penerapan PSAK 109 memiliki pengaruh terhadap pengelolaan dana zakat. Hasil ini relevan dengan Fadilah (2018), Muhammad (2016), serta Yuliafitri dan Khoiriyah (2016) mengatakan penerapan 
PSAK No 109 Tentang Standar Akuntansi Zakat berpengaruh positif dan signifikan pada Pengelolaan Zakat sebesar 37\%, untuk sisanya dipengaruhi oleh faktor lain yang mempengaruhi pengelolaan zakat.

Pengaruh Akuntabilitas, Transparansi, dan Penerapan Standar Akuntansi Syariah (PSAK 109) Secara Simultan terhadap Pengelolaan Dana Zakat

Berdasarkan hasil pengujian variabel akuntabilitas, transparansi dan penerapan PSAK 109 secara simultan berpengaruh positif dan signifikan terhadap pengelolaan dana zakat. Pengaruh yang positif tersebut dapat diartikan bahwa akuntabilitas, transparansi dan penerapan PSAK 109 yang baik akan meningkatkan pengelolaan dana zakat yang baik pula, sehingga agar di OPZ di Kota Bogor berjalan dengan baik perlu adanya akuntabilitas, transparansi dan penerapan PSAK 109. Dan ketiga faktor tersebut seharusnya dilakukan secara optimal dan bersamaan.

Pentingnya akuntabilitas, transparansi dan penerapan satndar akunatnsi syariah (PSAK 109) pada pengelolaan dana zakat agar dapat terlaksananya pertanggungjawaban laporan keuangan dalam memberikan informasi tentang laporan yang sesungguhnya, laporan pertanggungjawaban OPZ disampaikan kepada masyarakat dan telah mencerminkan kepentingan dan kebutuhan, terciptanya Informasi mengenai pengelolaan zakat dapat dengan mudah diakses oleh muzakki. Maka dapat disimpulkan bahwa akuntabilitas, transparansi dan penerapan PSAK 109 secara bersama-sama sangat berpengaruh terhadap pengelolaan dana zakat. Hal ini sesuai dengan penelitian Fadilah (2018) dan Muhammad (2016), dari hasil penelitiannya menyatakan bahwa aspek akuntabilitas dan transparansi berpengaruh secara simultan terhadap pengelolaan dana zakat yang ada di Kabupaten Sukoharjo.

SIMPULAN DAN SARAN Simpulan
1. Akuntabilitas secara parsial berpengaruh positif dan signifikan terhadap pengelolaan dana zakat di Kota Bogor. Pengaruh positif dan signifikan menunjukan bahwa akuntabilitas mempunyai peranan yang sinifikan/penting dalam meningkatkan pengelolaan dana zakat yang ada di Kota Bogor.

2. Transparansi secara parsial berpengaruh positif dan signifikan terhadap pengelolaan dana zakat di Kota Bogor. Pengaruh positif dan signifikan menunjukan bahwa transparansi mempunyai peranan yang sinifikan/penting dalam meningkatkan pengelolaan dana zakat yang ada di Kota Bogor.

3. Penerapan standar akunatansi syariah (PSAK 109) secara parsial berpengaruh positif dan signifikan terhadap pengelolaan dana zakat di Kota Bogor. Pengaruh positif dan signifikan menunjukan bahwa penerapan PSAK 109 mempunyai peranan yang sinifikan/penting dalam meningkatkan pengelolaan dana zakat yang ada di Kota Bogor.

4. Akuntabilitas, Transparansi dan Penerapan standar akuntansi syariah (PSAK 109) secara simultan berpengaruh positif dan signifikan terhadap pengelolaan dana zakat. Pengaruh positif dan signifikan menunjukan bahwa akuntabilitas, transparansi dan penerapan PSAK 109 mempunyai peranan yang sigifikan/penting dalam meningkatkan pengelolaan dana zakat yang ada di Kota Bogor.

\section{Saran}

1. Saran untuk penelitian selanjutnya dapat memperluas penggunaan variabel independen yang diduga menjadi faktor-faktor yang berpengaruh terhadap pengelolaan dana zakat.

2. Penelitian ini hanya menggunakan 6 sampel organisasi pengelola zakat 
yaitu BAZ dan LAZ, disarankan untuk penelitian selanjutnya dapat memperluas sampel penelitian baik lembaga maupun jumlah respondennya.

3. Penelitian selanjutnya disarankan untuk melakukan penelitian dengan populasi penelitian di lokasi atau daerah yang berbeda.

\section{DAFTAR PUSTAKA}

Al-Qur'an dan terjemahan. Departemen Agama Republik Indonesia. Jakarta. 2008.

Arikunto, S. (2014). Prosedur Penelitian. Jakarta: Rineka Cipta.

BAZNAS Badan Amil Zakat Nasional. 2018. Laporan 4 Tahun BAZNAS Kota Bogor tahun 2014-2017. Bogor (ID): BAZNAS Kota Bogor.

BAZNAS dan Fakultas Ekonomi dan Manajemen IPB. 2011. Estimasi Potensi Zakat Nasional. Majalah Sabili. No. 24/XVIII.

Fatmawati. 2017. Pengaruh Shariah Compliance, Transparansi, Akuntabilitas Dan Kompetensi Sumber Daya Manusia (Sdm) Terhadap Pengelolaan Dana Zakat Studi Pada Organisasi Pengelola Zakat Di Kabupaten Sukoharjo. Jurusan Akuntansi Syariah. Fakultas Ekonomi dan Bisnis Islam. IAIN Surakarta.

Ghozali, Imam. 2016. Aplikasi Analisis Multivariete Dengan Program IBM SPSS 23 (Edisi 8). Cetakan ke VIII. Semarang : Badan Penerbit Universitas Diponegoro.

Ikatan Akuntansi Indonesia (IAI). 2010. PSAK No.109

Tentang Pernyataan Akuntansi Keuangan. Jakarta. IAI.

Ikatan Akuntan Indonesia. (2015). PSAK 45: Laporan Keuangan Entitas Nirlaba (Edisi Revisi). Jakarta: Ikatan Akuntan.
4. Teknik pengambilan sampel penelitian ini hanya menggunakan instrumen berupa kuesioner yang dibagikan kepada responden saja, untuk penelitian selanjutnya disarankan untuk menggunakan instrumen lain seperti wawancara supaya terhindar dari timbulnya perbedaan interpretasi atas maksud dan tujuan pernyataan.

Khoiriyah dan Indri. 2016. Pengaruh Kepuasan Muzakki, Transparansi dan Akuntabilitas pada Lembaga Amil Zakat terhadap Loyalitas Muzakki (Studi Persepsi pada LAZ Rumah Sakit). Jurnal Ekonomi

Kristin P, A., \& Umah, U. K. (2011). Penerapan Akuntansi Zakat Pada Lembaga Amil Zakat (Studi Pada LAZ DPU DT Cabang Semarang). Jurnal Unimus. Voume 7 No. 2. Hal 68-97. Semarang: UNIMUS.

Kusuma, I. C., Nurfitri, R., \& Mukmin, M. N. (2019). Pengaruh Pressure, Opportunity, Rasionalization Dan Capability Terhadap Kecenderungan Kecurangan Akuntansi (Fraud). JURNAL AKUNIDA, 5(1), 54-68.

Mardiasmo. 2002. Akuntansi Sektor Publik, Cet. I. Yogyakarta: Andi.

Muhammad, R. (2016). Akuntabilitas Keuangan Pada Organisasi Pengelola Zakat (OPZ) Di Daerah Istimewa Yogyakarta. Journal of Accounting and Investment, 7(1), 34-55.

Nurhayati, N., Fadilah, S., Iss, A., \& Oktaroza, M. L. (2018). Pengaruh Kualitas Informasi Akuntansi, Akuntabilitas Dan Transparansi Pelaporan Keuangan Terhadap Tingkat Penerimaan Dana Zakatpada Badan Amil Zakat (Baz) Di Jawa Barat. Prosiding 
SNaPP: Sosial, Ekonomi Dan Humaniora, 4(1), 577-584.

Setiawan, A. B., \& Andris, A. (2019). Analisis Faktor-Faktor Yang Mempengaruhi Pengalokasian Anggaran Belanja Modal Pada Kabupaten/Kota Di Provinsi Jawa Barat. JURNAL AKUNIDA, 5(1), 1-9.

Sugiyono. 2018. Metode Penelitian Kualitatif, Kuantitatif dan R\&D. Alfabeta. Bandung.

Undang-Undang Republik Indonesia nomor 23 Tahun 2011 tentang: Pengelolaan Zakat.
Yuliafitri, I., \& Khoiriyah, A. N. (2016). Pengaruh Kepuasan Muzakki, Transparansi dan Akuntabilitas Pada Lembaga Amil Zakat Terhadap Loyalitas Muzakki (Studi Persepsi Pada LAZ Rumah Zakat). Islamiconomic: Jurnal Ekonomi Islam, 7(2).

Wawanncara dengan 13 muzakki di Mesjid Raya Kota Bogor (pada tanggal 04 Januari 2019).

http://bps.go.id. (diakses pada tanggal 16 Desember 2018).

http://pusat.baznas.go.id/profil//diakses pada tanggal 17 Maret 2019). 